\title{
KAPABILITAS ORGANISASI DINAS PERTANIAN TANAMAN PANGAN BAGI PENINGKATAN PRODUKSI KOMODITAS PADI DI KABUPATEN SUBANG TAHUN 2016-2018
}

\section{THE ORGANIZATIONAL CAPABILITY OF THE LOCAL OFFICE OF AGRICULTURE AND FOOD PLANTATION FOR IMPROVING THE RICE COMMODITY PRODUCTION IN SUBANG REGENCY YEAR 2016-2018}

\author{
Suherlan ${ }^{1 *}$, Asep Sumaryana ${ }^{2}$, Rita Myrna ${ }^{3}$, Josy Adiwisastra ${ }^{4}$ \\ ${ }^{1}$ Mahasiswa Program Doktor, Universitas Padjadjaran, Bandung \\ 2,3Dosen Tetap Fakultas Ilmu Sosial dan Ilmu Politik, Universitas Padjadjaran, Bandung \\ ${ }^{4}$ Dosen Tetap Magister Ilmu Pemeritahan, Universitas Langlang Buana, Bandung \\ *Korespondensi: Suherlan. Email: suherlanfia@gmail.com
}

(Diterima: 18-06-2019; Ditelaah: 02-07-2019; Disetujui: 12-07-2019)

\begin{abstract}
The organizational capability of the Local Office of Agriculture and Food Plantation for improving the rice commodity production in Subang Regency year 2016-2018 had not been suitable yet with the plan of the Local Government of Subang Regency as regulated in the Local Regulation No. 14/2014 concerning the Local Middle Term Development Plan of Subang Regency Year 2014-2018 in order to increase the rice commodity production from 1.1 million ton to 1.6 million ton. The aim of this research is to describe the organizational capability of the Local Office of Agriculture and Food Plantation for improving the rice commodity production. The method of this research is descriptive. This research uses the primary and secondary data. The data of this research is qualitatively analyzed. The results of this research indicate that the organizational capability for improving the rice commodity production could not develop the new irrigation and optimize the rice field land yet. Moreover, the rice plantation time planned three times a year was not achieved because of the lack of water supply. Consequently, the achievement of rice commodity production in last 2018 was only 1.3 million ton. The knowledge and skills of the civil servants at field could not be practiced yet. The organizational capability had not been suitable yet with the program of irrigation reconstruction and the supporting infrastructures. Therefore, the Local Office of Agriculture and Food Plantation and other local organizations related to the agricultural sector had not optimally co-operated yet.
\end{abstract}

Keywords: Organizational Capability, Rice Commodity, Agriculture and Food Plantation.

\begin{abstract}
ABSTRAK
Kapabilitas Organisasi Dinas Pertanian Tanaman Pangan bagi Peningkatan Produksi Komoditas Padi Tahun 2016-2018 belum sesuai dengan rencana Pemerintah Daerah Kabupaten Subang sebagaimana diatur dalam Peraturan Daerah Nomor 14 Tahun 2014 tentang Rencana Pembangunan Jangka Menengah Daerah Kabupaten Subang Tahun 2014-2018 untuk meningkatkan produksi komoditas padi dari 1,1 juta ton menjadi 1,6 juta ton. Adapun tujuan dari penelitian ini adalah untuk mengetahui kapabilitas organisasi Dinas Pertanian Tanaman Pangan bagi peningkatan produksi komoditas padi. Metode penelitian bersifat deskriptif. Data yang diperlukan adalah data primer dan sekunder. Data dianalisis secara kualitatif. Hasil penelitian menunjukkan bahwa kapabilitas organisasi bagi peningkatan produksi komoditas padi belum dapat membangun saluran irigasi baru dan mengoptimalkan lahan sawah. Selain itu, masa tanam padi yang direncanakan tiga kali setahun tidak tercapai karena kekurangan pasokan air. Akibatnya, pencapaian hasil produksi komoditas padi pada akhir tahun 2018 hanya sebesar 1,3 juta ton. Pengetahuan dan keahlian para pelaksana tugas di lapangan belum dapat diterapkan. Kapabilitas organisasi belum sesuai dengan program perbaikan jaringan irigasi dan sarana pendukungnya. Oleh karena itu, Dinas Pertanian Tanaman Pangan dan Organisasi Perangkat Daerah sektor pertanian belum bekerja sama dengan maksimal.
\end{abstract}

Kata Kunci: Kapabilitas Organisasi, Komoditas Padi, Pertanian dan Tanaman Pangan.

Suherlan. 2019. Kapabilitas Organisasi Dinas Pertanian Tanaman Pangan bagi Peningkatan Produksi Komoditas Padi di Kabupaten Subang Tahun 2016-2018. 


\section{PENDAHULUAN}

Pemerintah berencana meningkatkan produktivitas padi untuk mewujudkan swasembada pangan ke depan dan sekaligus untuk menghapus impor beras dari luar negeri seperti Vietnam, Thailand, India, dan China. Guna merealisasikan program tersebut Presiden memerintahkan Menteri Pertanian supaya mengadakan hubungan kerja sama dengan Pemerintah Provinsi dan Kabupaten/Kota serta stakeholder lainnya seperti kerja sama dengan TNI-POLRI.

Sebagai upaya untuk mewujudkan ketahanan pangan nasional, Pemerintah Pusat menerbitkan SK Menteri Pertanian Republik Indonesia Nomor. 1243/Kpts/ OT.160/12/2014 tentang Kelompok Kerja Upaya Khusus Peningkatan Produksi Padi, Jagung, dan Kedelai melalui program perbaikan jaringan irigasi dan sarana pendukungnya. Pertimbangan SK tersebut adalah bahwa dalam rangka peningkatan produksi padi, jagung, dan kedelai diperlukan perbaikan jaringan irigasi dan sarana pendukungnya, dan bahwa agar dalam pelaksanaan peningkatan produksi padi, jagung, dan kedelai dapat berjalan lancar dan berhasil baik, perlu membentuk kelompok kerja upaya khusus peningkatan produksi padi, jagung, dan kedelai melalui program perbaikan jaringan irigasi dan sarana pendukungnya. Program kerja sama ketahanan pangan TNI/POLRI dan Pemerintah Daerah Kabupaten Subang diyakini mampu menggenjot target produksi gabah kering giling (GKG) dari 1,1 juta ton jadi 1,6 juta ton. Solusinya adalah dengan melalui program normalisasi irigasi dan optimasi lahan, ketersediaan pupuk, pestisida, benih unggul dan sistem pola tanam, sehingga produksi GKG yang semula rata-rata tujuh ton per hektar bisa meningkat jadi 9,2 ton per hektar. Terdapat puluhan ribu hektar lahan persawahan yang kurang produktif akan diubah menjadi sawah produktif melalui program kerja sama ketahanan pangan antara Pemerintah Kabupaten setempat dengan KODIM 0605 Sunan
Gunung Jati. (Tempo. co, Subang, 27 Desember 2014).

Data Dinas Pertanian Tanaman Pangan Kabupaten Subang tahun 2016 menunjukkan bahwa luas wilayah Kabupaten Subang mencapai 205.176 hektar. Berdasarkan penggunaannya sekitar 84.570 hektar digunakan sebagai lahan sawah yang tidak mengalami perubahan sejak tahun 2014 dan sisanya sebagai lahan kering. Sebagian besar $(67,38$ persen) lahan sawah di Kabupaten Subang sudah merupakan sawah dengan pengairan irigasi teknis, kemudian 13,14 persen berpengairan irigasi setengah teknis dan hanya 5,35 persen yang berpengairan non teknis. Namun demikian, bila dicermati masih terdapat 10 Kecamatan yang lahan sawahnya belum berpengairan teknis, yaitu Kecamatan Sagalaherang, Serangpanjang, Jalancagak, Ciater, Cisalak, Kasomalang, Tanjungsiang, Subang, Kalijati dan Cipeundeuy. Kualitas pengairan sangat berperan besar pada peningkatan produksi tanaman pangan di Kabupaten Subang. Untuk itu perlu upaya peningkatan dan pemeliharaan jaringan pengairan.

Berdasarkan latar belakang dan hasil observasi peneliti pada Dinas Pertanian Tanaman Pangan dan Organisasi Perangkat Daerah (OPD) lain yang terkait dengan sektor pertanian di Kabupaten Subang, diketahui bahwa kapabilitas organisasi Dinas Pertanian Tanaman Pangan bagi Peningkatan Produksi Komoditas Padi di Kabupaten Subang Tahun 2016-2018 belum sepenuhnya maksimal karena belum sesuai dengan Peraturan Daerah Kabupaten Subang Nomor 14 Tahun 2014 tentang Rencana Pembangunan Jangka Menengah Daerah Kabupaten Subang Tahun 20142018. Hal ini terlihat dari adanya indikasiindikasi permasalahan sebagai berikut:

1) Kapabilitas organisasi yang dimiliki Pemerintah Daerah dari unit-unit seperti kelembagaan, sumber daya manusia, dan teknis belum dapat sepenuhnya dioperasionalisasikan berdasarkan prinsip-prinsip pengetahuan dan keahlian yang efektif dan efisien 
oleh Dinas Pertanian Tanaman Pangan dan OPD lain yang terkait dengan sektor pertanian di Kabupaten Subang. Terdapat satu indikator dalam dimensi ini yang belum dapat direalisasikan, yaitu specific technique, dimana cara-cara untuk membuat terobosan-terobosan baru yang secara khusus belum dapat dilakukan sehingga upaya pencapaian tujuan organisasi belum dapat sepenuhnya dicapai oleh Dinas Pertanian Tanaman Pangan dan OPD lain yang terkait dengan sektor pertanian. Secara teknis dapat terlihat dari target sasaran luas irigasi kabupaten dalam kondisi baik, capaian kinerja yang diharapkan pada akhir RPJMD (tahun 2018) adalah sebesar 65\%, sehingga capaian kinerja sampai dengan tahun 2017 baru mencapai 57,50\% dari target RPJMD. (Dinas Pertanian Tanaman Pangan Kabupaten Subang, 2018).

2) Kemampuan Pemerintah Daerah dalam mengelola hubungan kerja sama dengan internal dan eksternal organisasi terkait belum dapat berintegrasi dalam hal kesamaan tindakan pencapaian tujuan yang diinginkan. Hal ini terjadi karena kapabilitas organisasiorganisasi dalam sektor pertanian belum dapat beradaptasi sepenuhnya dengan lingkungan yang mempunyai kepentingan dan keterkaitan dengan target peningkatan produksi komoditas padi. Terdapat indikator ways of creating knowledge dari dimensi managerial systems, yaitu kebiasaan atau cara-cara menciptakan ilmu pengetahuan, program-program masa belajar sebagai keahlian atau sebagai arena membuat jaringan-jaringan kerja dengan sejumlah partner. Indikator ways of creating knowledge ini belum dapat diimplementasikan sepenuhnya dalam kapabilitas Pemerintah Daerah yang pada tahapan proses implementasi kebijakannya sudah didelegasikan kepada organisasi-organisasi perangkat daerah yang terkait dalam upaya target peningkatan pencapaian produktivitas dan produksi padi di Kabupaten Subang. Secara teknis, hal ini terlihat dari realisasi produksi padi tahun 2018 sebesar 1.313.764,09 ton dan produktivitasnya mencapai 70,15 kw/ha (Dinas Pertanian Tanaman Pangan Kabupaten Subang, 2018).

Penelitian terdahulu tentang organisasi sektor pertanian atau organisasi ketahanan pangan khususnya pada komoditas padi baru diteliti dari aspek-aspek berbeda sebagaimana penelitian terdahulu yang sudah dilakukan oleh Azwardi, et al (2006), dan Arshad, et al (2011). Berikut ini peneliti sajikan kedua dari hasil penelitian terdahulu tersebut:

1. Hasil penelitian terdahulu yang pernah dilakukan oleh Azwardi, et al (2006) yang berjudul "The Effect of Subsidy Policy on Food Security of Rice in Indonesia", yaitu tentang dampak kebijakan subsidi terhadap ketahanan pangan pada komoditas padi di Indonesia. Dalam hal ini, penelitiannya mengamati ketahanan pangan pada komoditas padi dari aspek kebijakan subsidi yang berdampak kepada masyarakat dan juga kepada pemerintah itu sendiri di Indonesia. Tujuan dari penelitiannya adalah untuk mengamati atau mencari dampak dari subsidi nonenergi terhadap ketahanan panagan pada komoditas padi di Indonesia. Adapun metode yang digunakan dalam mengalisis kajiannya yaitu pendekatan model persamaan secara serentak atau pendekatan Simultaneously Equation Model (SEM) yang menggunakan sedikitnya dua tingkatan kuadrat atau Two Stage Least Squares (2SLS). Sedangkan hasil dan temuaan-temuan dalam penelitiannya menunjukkan bahwa kebijakan subsidi menentukan konsumsi beras di Indonesia dan subsidi tersebut dipengaruhi oleh harga padi/beras. Kondisi ini menunjukkan bahwa pemerintah harus berusaha menjaga stabilitas harga beras melalui subsidi dan juga harus mencoba menetapkan 
ketahanan pangan yang baik dari sisi permintaan dan persediaan.

2. Penelitian terdahulu lainnya dilakukan oleh Arshad, et al (2011) yang berjudul Food Security: Self-Sufficiency of Rice in Malaysia, yaitu ketahanan pangan: kemandirian pangan/padi di Malaysia. Penelitian ini menguji pengaruh konversi dan kesuburan lahan sawah dipandang dari aspek strategi dan prinsip kemandirian pangan di Malaysia. Tujuan penelitiannya adalah menguji pengaruh pupuk dan subsidi langsung, begitu juga dengan konvesrsi lahan dan kesuburan terhadap tingkat kemandirian padi. Metode yang digunakan dalam penelitiannya adalah model dinamik sistem, merupakan sebuah model yang diterapkannya untuk menganalisis hubungan-hubungan sebab akibat dan timbal balik dari variabelvariabel dalam kerangka kerja sistem produksi padi. Adapun hasil penelitiannya menunjukkan bahwa Malaysia tidak mungkin mampu menyokong tingkat kemandirian yang ditargetkan tanpa R\&D yang cukup untuk menujukan batasan-batasan produksi khususnya produktivitas di bawah-jumlah maksimum dan ancaman-ancaman perubahan cuaca atau iklim. Di lain sisi konsumsi beras terus meningkat karena pertambahan jumlah penduduk.

Adapun penelitian peneliti (2019) yang berjudul Organizational Capability of the Local Office of Agriculture and Food Plantation within Rice Commodity in Subang Regency Year 2016-2018, yaitu kapabilitas organisasi Dinas Pertanian Tanaman Pangan dalam komoditas padi di Kabupaten Subang tahun 2016 hingga tahun 2018. Penelitian ini menganalisis proses peningkatan produksi komoditas padi dipandang dari aspek kapabilitas organisasi di Kabupaten Subang. Terdapat relevansi dengan hasil penelitian terdahulu di atas, hanya pendeskripsian objeknya berbeda lokus, dan memandang objek penelitian dari aspek berbeda pula. Adapun persamaannya dengan penelitian peneliti, yaitu pentingnya peranan organisasi mengkoordinasikan dan mengintegrasikan perencanan atau program yang melibatkan peranan pemerintah beserta stakeholder terkait lainnya dalam rangka mencapai tujuan yang telah ditetapkan sebelumnya. Selanjutnya, peneliti mengangkat pertanyaan penelitian dalam perumusan masalah sebagai berikut: Mengapa kapabilitas organisasi Dinas Pertanian Tanaman Pangan bagi peningkatan produksi komoditas padi di Kabupaten Subang tahun 2016 sampai 2018 belum sepenuhnya maksimal?

\section{MATERI DAN METODE}

\section{Teori/Konsep yang Relevan}

Kapabilitas organisasi menurut Collis (1994) merupakan konsep yang digunakan untuk merumuskan pengertian dari sumber-sumber daya berbasis teori yang kokoh dan kuat mengenai sumber daya organisasi dari kinerja atau prestasi yang tinggi. Menurut Winter (2003), "organizational capability is essentially constituted by the high-level organizational practices used to coordinate the productive activities of the firm". Kapabilitas organisasi penting dibangun oleh praktik-praktik organisasi level atas yang dipergunakan untuk mengkoordinasikan kegiatan-kegiatan organisasi yang produktif.

Kapabilitas organisasi dikatakan sebagai sebuah konsep karena berkaitan dengan perumusan tentang bagaimana sumber daya yang dimiliki sebuah organisasi dapat mencapai dan menghasilkan kinerja yang sudah ditetapkan. Di lain pihak, kapabilitas organisasi dapat dikatakan sebagai praktik organisasi level atas karena dibangun berdasarkan pertimbangan dan keputusankeputusan penting dalam suatu organisasi dengan cara mengkoordinasikan semua unit dan juga kegiatan untuk tercapainya tujuan yang telah ditetapkan sebelumnya sehingga apapun kebijakan dan aktivitas yang dilakukan organisasi dapat mencapai hasil yang produktif. Terdapat hubungan 
antara kapabilitas dan atribut organisasi secara khusus nampaknya penting dalam bentuk birokrasi-birokrasi profesional yang terdapat di sektor publik, yang mungkin kurang terbuka terhadap kekuatan pasar dan lebih sedikit memiliki ruang terhadap manuver strategis. Birokrasi profesional dalam sektor publik merupakan fasilitator yang mewadahi serta menghubungkan kapabilitas dan atribut organisasi yang dalam menjalankan fungsinya dianggap kurang terbuka dan ada kecendrungan menutupi diri dalam hal transparansinya di hadapan publik atau masyarakat pada umumnya. Sementara itu, Talbot dan Johnson (2007) mengatakan bahwa "Politicians and policy-makers' responses to perceived weaknesses in the capabability of public organizations inva-riably involve attempts to restructure those organizations. So, for instance, central government departements and agencies may be merged or disagregated depending on whether their size is perceived to be a help or a hindrance to the work that they do". Munculnya berbagai respon dari para politisi dan pembuat kebijakan terhadap permasalahan yang berkaitan langsung dengan dan tentang kelemahan kelemahan yang dirasakan di dalam kapabilitas organisasi publik yang selalu menghubungkan percobaanpercobaan untuk menyusun kembali organisasi-organisasi tersebut.

Richard Whitley (2007: 149) mengemukakan tentang awal berkembangnya dan yang menjadi perhatian kapabilitas organisasi bahwasanya yang menjadi pusat pengembangan kapabilitas organisasi secara khusus adalah: (1) Adanya keinginan dari para pegawai, oleh karena kapabilitas organisasi berkembang dan menjadi penting dilatarbelakangi dengan adanya keinginan-keinginan para pegawai untuk berkomitmen terhadap pemecahan permasalahan yang sedang dihadapi. (2) Adanya keinginan besar dari para pegawai untuk meningkatkan dan mengembangkan ilmu pengetahuan, keahlian-keahlian yang sangat spesifik. (3) Adanya keinginan para pegawai untuk senantiasa memperoleh biaya-biaya guna meningkatkan dan mengembangkan kompetensi dan nilai-nilai individu dalam rangka pemenuhan tuntutan kebutuhan organisasi.

Core capabilities merupakan intisari dan dimensi dari kapabilitas organisasi sebagaimana diungkapkan oleh Leonard dan Barton (1992: 4-5) yang menjelaskan sebagai bidang pengetahuan yang membedakan dan juga memberikan keuntungan secara kompetitif. Core capabilities sebagaimana diungkapkan oleh Leonard dan Barton (1992: 4-5) tersebut meliputi empat dimensi, yaitu knowledge and skills, technical systems, managerial systems, dan values and norms.

Dimensi Pertama: Knowledge and Skills. Dimensi knowledge and skills mencakup dua indikator, yaitu: (1) specific techniques (associated with core capabilities) dan (2) scientific understanding (relevant to new product development). Ilmu pengetahuan dan ketrampilan yang meliputi indikator-indikator teknik spesifik yang (dihubungkan dengan intisari kapabilitas) dan pemahaman ilmiah (berhubungan dengan perkembangan produk baru). Pengetahuan sangat fundamental dan sesuatu yang vital dalam sebuah organisasi dimana kegiatan-kegiatan dalam organisasi dapat berjalan sebagaimana mestinya manakala didukung oleh sumber daya yang ada dalam organisasi tersebut, termasuk sumber daya manusia yang memiliki pengetahuan luas serta mumpuni dalam menjalankan tugas-tugas pokok dan fungsinya di dalam organisasi tempat dia bekerja. Coo (2006: 1) menyatakan tentang pentingnya pengetahuan ini bahwa "the use of knowing instead of knowledge also underscores our view that knowledge is the result of collective action and reflection, and not simply the acquisition of things and objects that somehow contain knowledge". Penggunaan kata knowing dan knowledge itu mempunyai persamaan makna dan arti dan begitu juga menegaskan pandangan bahwa pengetahuan merupakan hasil dari tindakan dan refleksi kolektif dan bukan semata-mata perolehan dari sesuatu dan objek-objek 
yang bagaimanapun juga terdiri dari dan berisi pengetahuan. Keahlian merupakan bekal dan/atau modal seseorang dalam sebuah organisasi baik sebagai pegawai ataupun manajer. Dengan keahlian, sebagai pegawai atau manajer dapat melakukan sesuatu dengan terampil dan juga baik sebagaimana telah dinyatakan oleh Hornby dan Gimson et al (1983: 804) bahwa "skill is the ability to do something expertly and well".

Dimensi Kedua: Technical Systems. Dimensi technical systems mencakup dua indikator, yaitu informasi dan prosedur. Leonard dan Barton mengemukakan bahwa "this knowledge constitutes both information (e.g. a data base of product tests conducted over decades) and procedures (e.g. proprietary design rules)". Sesuatu yang dibangun dengan informasi (sebagai contohnya, menyajikan dan memberikan informasi dengan sebuah database berkenaan dengan pengujian-pengujian produk yang diadakan akhir dekade). Sedangkan yang dibangun melalui prosedur (seperti aturan yang didisain oleh pemilik). Socio-technical systems approach adalah salah satu aliran manajemen yang diacu lebih baru ini. Koontz, et al (1992: 66) menyatakan bahwa dalam penanganan masalah produktivitas, misalnya, mereka menemukan bahwa sistem teknik (mesin dan metode) memiliki dampak kuat atas sistem sosial. Dengan kata lain, sikap pribadi dan perilaku kelompok dipengaruhi oleh sistem teknik di tempat kerja.

Dimensi Ketiga: Managerial Systems. Dimensi managerial systems mencakup dua indikator, yaitu: (1) ways of creating knowledge (e.g. through sabbaticals, apprenticeship programs or networks with partners) dan (2) ways of controlling knowledge (e.g. incentive systems and reporting structures). Kebiasaan atau caracara menciptakan ilmu pengetahuan, (sebagai contoh, melalui cuti besar atau cuti panjang untuk beristirahat, programprogram masa belajar sebagai keahlian atau jaringan-jaringan kerja dengan sejumlah patner). Dan kebiasaan atau cara-cara mengontrol ilmu pengetahuan seperti sistem insentif dan struktur-struktur tentang pelaporan. Chester I. Barnard menunjukkan pandangannya bahwa eksekutif sebagai komponen suatu organisasi formal dan organisasi itu sendiri dianggapnya sebagai bagian dari keseluruhan sistem kerja sama yang melibatkan unsurunsur fisik, biologis, sosial, dan psikologis. Dengan memasukkan unsur-unsur fisis, biologis, sosial, dan psikologis ke dalam sistem dimana manajer bekerja, Barnard menganggap penggambaran itu lebih akurat mengenai subsistem manajerial jika dibandingkan dengan pandangan ahli psikologi sosial pada umumnya yang hanya menggabungkan dengan sistem sosial. Sesungguhnya, kebanyakan dari interaksi seorang manajer berkaitan dengan kekuatan dan unsur-unsur sosial dan psikologis. Tetapi sukarlah untuk tidak melihat seorang manajer berinteraksi dengan unsur-unsur lain, khususnya dengan unsur-unsur fisis seperti uang, bahan, dan fasilitas (Koontz et al, 1992: 18-19). Interaksi dengan lingkungan sangat penting dalam kehidupan berorganisasi agar tujuan-tujuannya dapat dicapai dengan maksimal. Dalam hal ini, sistem manajerial perlu mendapatkan dan menciptakan pengetahuan baru dalam menjalankan aktivitas-aktivitasnya. Nonaka dan Takeuchi (1995: 196) mengatakan bahwa "knowledge creation is that an organization creates new knowledge through the interaction and conversion between its tacit and explicit knowledge. A cycle of four processes are involved: socialization, externalization. combination. and internalizetion". Maksudnya ialah bahwa penciptaan pengetahuan adalah sebuah organisasi menciptakan pengetahuan baru melalui interakaksi dan pengubahan diantara pengetahuannya yang tacit dan eksplisit.

Dimensi Keempat: Values and Norms. Dimensi values and norms mencakup tiga indikator, yaitu: (1) Content and structure of knowledge (e.g. chemical engineering vs. marketing expertise; 'open-systems' software 
vs. proprietary systems). (2) Means of collecting knowledge (e.g. formal degrees vs. experience). (3) Controlling knowledge (e.g. individual empowerment vs. management hierarchies). Values dan norms merupakan salah satu dimensi dari kapabilitas organisasi yang dengan nilai-nilai dan norma-norma tersebut dimensi ini merupakan bagian yang sangat penting dalam organisasi untuk menghadapi berbagai perasalahan baik yang berurusan dengan permasalahan di dalam organisasi maupun di luar organisasi. Starkey (1996: 150) mengartikan norms sebagai perilaku yang diharapkan dan/atau diinginkan; apabila dilanggar, maka individu atau kelompok tersebut akan dikecam secara informal. Secara umum, organisasi yang sangat inovatif mempunyai norma-norma yang memberi tekanan tidak formal di dalam perilaku, berpakaian, hubunganhubungan bawahan dengan atasan; standar kerja yang tinggi dan harapan-harapan kinerja individu atau kelompok, fleksibilitas di dalam pembuatan keputusan, pemecahan masalah, dan pola-pola resolusi konflik, dan hubungan-hubungan informal yang kuat di dalam dan di luar organisasi.

\section{Metode}

Penelitian ini bertujuan untuk menemukan konsep baru tentang kapabilitas organisasi sebagai bagian dari ilmu administrasi publik dalam rangka penyempurnaan proses kebijakan melalui penelitian tentang kapabilitas organisasi Dinas Pertanian Tanaman Pangan bagi peningkatan produksi komoditas padi di Kabupaten Subang Provinsi Jawa Barat tahun 2016-2018. Dengan demikian, metode penelitian yang tepat digunakan untuk mencapai tujuan penelitian adalah model kualitatif. Hal ini sejalan dengan pendapat Bogdan (1993) yang mengatakan bahwa "model penelitian kualitatif merupakan prosedur penelitian untuk menghasilkan data deskriptif berupa kata-kata tertulis atau lisan dari orang-orang dan perilaku yang dapat diamati".
Penelitian kualitatif digunakan untuk memahami fenomena tentang subyek penelitian dalam hal ini "kapabilitas organisasi" yang dilaksanakan mengarah pada penyusunan suatu teori ilmiah berdasarkan data yang dalam konteks ini menemukan gambaran model teoritik organisasi yang bertanggung jawab atas "ketahanan pangan pada komoditas padi". Hal ini sesuai dengan pendapat Strauss dan Corbin (2003: 19) bahwa "qualitative methods can be used to uncover and understand what lies behind any phenomenon about which liltle to yet known ..., qualitative methods can give the indicate details if phenomenon that are difficult to convey with qualitative method".

Fenomena yang dimaksud misalnya perilaku, persepsi, motivasi, tindakan, dan lainnya yang secara holistik berkenaan dengan penyelenggaraan kapabilitas organisasi dalam rangka ketahanan pangan dalam komoditas padi, dan mendeskripsikan dalam bentuk kata-kata dan bahasa yang menggambarkan kapabilitas organisasi ketahanan pangan pada komoditas padi di Kabupaten Subang Provinsi Jawa Barat pada suatu konteks khusus yang ilmiah dan dengan memanfaatkan berbagai metode ilmiah.

\section{HASIL DAN PEMBAHASAN}

Pembahasan hasil penelitian didasarkan pada dimensi-dimensi kapabilitas oganisasi sebagai berikut:

Dimensi Pertama: Knowledge and Skills. Dinas Pertanian Tanaman Pangan dan Organisasi Perangkat Daerah (OPD) lain yang terkait dengan upaya peningkatan produktivitas dan produksi padi di Kabupaten Subang pada dasarnya sudah menjalankan proses specific technics dan scientific understanding di lapangan. Proses pelaksanaan dimensi ini berjalan dengan adanya rencana besar Pemerintah Kabupaten Subang untuk meningkatkan produktivitas dan produksi padi dari tahun ke tahun dengan menggunakan sumber daya yang dimilikinya melalui Dinas Pertanian 
Tanaman Pangan dan OPD lain terkait dengan sektor pertanian. Berdasarkan hasil penelitian dan pembahasan diketahui bahwa kapabilitas organisasi Pemerintah Daerah yang sudah mendelegasikan tugas dan wewenangnya dalam urusan pertanian kepada Dinas Pertanian Tanaman Pangan dan OPD lain terkait dengan sektor pertanian belum sepenuhnya mampu menjalankan indikator specific technics yang dengan indikator ini organisasi-organisasi terkait belum dapat melakukan terobosanterobosan baru dalam upaya mewujudkan target pencapaian peningkatan produktivitas dan produksi komoditas padi sesuai dengan yang ditetapkan, yaitu 1,6 juta ton.

Dimensi Kedua: Technical Systems. Kapabilitas Organisasi Pemerintah Daerah Kabupaten Subang dalam mengimplementasikan dimensi technical systems pada dasarnya sudah berjalan dengan semestinya terlihat adanya peningkatan produktivitas dan produksi komoditas padi dari tahun ke tahun. Terdapat dua hal yang dibangun melalui dimensi atau pengetahuan ini berupa informasi dan prosedur. Pertama, Kapabilitas Organisasi Pemerintah Daerah membangun saluran informasi secara hirarki dengan memberikan informasi berkenaan dengan aktivitas-aktivitas kelembagaan yang teruji yang dilakukan pada awal hingga akhir tahun kegiatan melalui Dinas Pertanian Tanaman Pangan sebagai leading sector beserta OPD lain terkait dengan bidang pertanian. Kedua, Organisasi Pemerintah Daerah Kabupaten Subang melalui Dinas Pertanian Tanaman Pangan dan OPD lain yang terlibat dalam upaya peningkatan pencapaian target produktivitas dan produksi komoditas padi secara hirarki membangun Standard Operational Procedures (SOP). Pembangunan prosedur tata kelola dan tata kerja kegiatan operasioanal dari leading sector Dinas Pertanian Tanaman Pangan sampai ke tingkat terbawah, yaitu kelompok tani di Kabupaten Subang.
Dimensi Ketiga: Managerial Systems. Managerial systems merupakan langkahlangkah pimpinan organisasi untuk melaksanakan tugas pokok dan fungsinya sesuai dengan visi dan misi yang diembannya agar dapat diwujudkan sesuai dengan tujuan yang sudah ditetapkannya. Dalam hal ini, sistem manajerial perlu mendapatkan dan menciptakan pengetahuan baru dalam menjalankan aktivitas-aktivitasnya dan program-program masa belajar sebagai keahlian atau sebagai arena membuat jaringan-jaringan kerja dengan sejumlah patner. Indikator ways of creating knowledge ini belum dapat dimplementasikan sepenuhnya dalam kapabilitas organisasi Dinas Pertanian Tanaman Pangan dan OPD lain yang terkait dalam upaya peningkatan produktivitas dan produksi komoditas padi di Kabupaten Subang tahun 2016 sampai 2018.

Dimensi Keempat: Values and Norms. Dimensi values and norms memberikan fondasi atau landasan dasar dari suatu unit bisnis. Intisari nilai merupakan kepercayaan tentang apa-apa yang baik atau jelek, apa yang benar atau apa yang salah di dalam suatu organisasi yang sangat teliti. Seperangkat intisari nilai jelas dapat membantu untuk fokus dan memotivasi perilaku. Norma adalah perilaku yang diharapkan dan/atau diinginkan; apabila dilanggar, maka individu atau kelompok tersebut akan dikecam secara informal. Interaksi dengan lingkungan sangat penting dalam kehidupan berorganisasi agar tujuan-tujuannya dapat dicapai dengan maksimal.

Dimensi values and norms terdiri dari tiga indikator. Indikator pertama, content and structure of knowledge merupakan konten dan struktur pengetahuan dari dimensi ini sudah berjalan dengan semestinya dalam praktik kapabilitas organisasi Pemerintah Daerah Kabupaten Subang yang didelegasikan kepada Dinas Pertanian Tanaman Pangan dan OPD lain yang terkait dalam sektor pertanian. Indikator kedua, means of collecting knowledge adalah cara 
mengoleksi pengetahuan antara tingkatan formal dan tingkatan pengalaman yang dimiliki oleh setiap pegawai dalam organisasi sudah dapat diimplementasikan sebagaimana mestinya. Indikator ketiga, conrolling knowledge berkaitan dengan mengontrol pengetahuan para pegawai dalam organisasi Pemerintah Daerah menyangkut pemberdayaan individu yang disesuaikan dengan hirarki manajemen dalam sebuah organisasi terkait dengan upaya-upaya peningkatan produktivitas dan produksi komoditas padi di Kabupaten Subang. Hal ini sudah dapat direalisasikan dan implementasinya sudah dapat dikombinasikan pada setiap aktivitas Organisasi Pemerintah Daerah Kabupaten Subang yang terkait dengan upaya-upaya peningkatan produktivitas dan produksi komoditas padi di Kabupaten Subang.

Hasil penelitian di atas dapat memberikan penjelasan bahwa Dinas Pertanian Tanaman Pangan dan Organisasi Perangkat Daerah yang terkait dalam bidang pertanian pada sektor pangan komoditas padi berupaya meningkatkan produksi komoditas ini dengan memperhatikan salah satu sarana pendukungnya yaitu air irigasi. Terdapat perkembangan di bidang saluran irigasi yang menunjukkan pencapaian kinerja dalam tiga kondisi, yaitu kondisi baik, kondisi sedang, dan kondisi rusak. Kondisi tersebut dapat dilihat dari Tabel 1.

Tabel 1. Perkembangan Kondisi Irigasi di Kabupaten Subang Tahun 2016-2018

\begin{tabular}{|c|c|c|c|c|c|c|c|}
\hline \multirow[b]{2}{*}{ No } & \multirow{2}{*}{$\begin{array}{l}\text { Kondisi } \\
\text { Irigasi }\end{array}$} & \multicolumn{2}{|l|}{2016} & \multicolumn{2}{|l|}{2017} & \multicolumn{2}{|l|}{2018} \\
\hline & & $\begin{array}{l}\text { Luas } \\
(\mathrm{Ha})\end{array}$ & $\%$ & $\begin{array}{l}\text { Luas } \\
(\mathrm{Ha})\end{array}$ & $\%$ & $\begin{array}{l}\text { Luas } \\
\text { (Ha) }\end{array}$ & $\%$ \\
\hline 1. & Baik & 10.634 & 53,90 & 11.345 & 57,50 & 12.252 & 62,10 \\
\hline 2. & Sedang & 4.558 & 23,10 & 4.794 & 24,30 & 4.577 & 23,20 \\
\hline 3. & Rusak & 4.538 & 23,00 & 3.591 & 18,20 & 2.901 & 14,70 \\
\hline & Jumlah & 19.730 & 100 & 19.730 & 100 & 19.730 & 100 \\
\hline
\end{tabular}
Sumber: Dinas Pertanian Tanaman Pangan Kabupaten Subang, 2018.

Sementara untuk indikator kinerja Dinas Pertanian Tanaman Pangan Kabupaten Subang dalam pencapaian kinerjanya dalam bidang produktivitas dan produksi komoditas padi dari tahun 2016 higga tahun 2018 dapat dilihat pada Tabel 2.
Tabel 2. Capaian Kinerja dalam Produksi dan Produktivitas Komoditas Padi Tahun 2016-2018

\begin{tabular}{lllll}
\hline No. & $\begin{array}{l}\text { Indikator } \\
\text { Kinerja }\end{array}$ & 2016 & 2017 & 2018 \\
\hline 1. & $\begin{array}{l}\text { Produksi Padi } \\
\text { ton) }\end{array}$ & $1.273 .133,31$ & $1.323 .110,55$ & $1.366 .575,57$ \\
\hline 2. & $\begin{array}{l}\text { Produktivitas } \\
\text { Padi (kw/ha) }\end{array}$ & 70,77 & 67,15 & 71,60 \\
\hline
\end{tabular}

Sumber: Dinas Pertanian Tanaman Pangan Kabupaten Subang, 2018.

\section{KESIMPULAN}

Kapabilitas organisasi Dinas Pertanian Tanaman Pangan bagi peningkatan produksi komoditas padi di Kabupaten Subang tahun 2016-2018 belum sepenuhnya maksimal karena alasan-alasan yang ditemukan sebagai berikut:

Pertama: knowledge and skills, yaitu pengetahuan dan keahlian-keahlian yang secara spesifik belum dapat sepenuhya tercapai dilaksanakan oleh Dinas Pertanian Tanaman Pangan dan OPD lainnya yang terkait dengan sektor pertanian untuk pencapaian target peningkatan produksi komoditas padi. OPD belum dapat merealisasikan langkah-langkah baru secara khusus sesuai dengan yang sudah direncanakan sebelumnya. Hal ini terlihat dari indikator specific technique yang terdapat dalam dimensi kapabilitas organisasi, yaitu knowledge and skills, yang dengan indikator tersebut cara-cara untuk membuat terobosan-terobosan baru secara khusus belum dapat dilakukan sehingga upaya untuk mendukung target peningkatan produktivitas dan produksi komoditas padi belum dapat sepenuhnya dicapai. Secara teknis terlihat bahwa capaian kinerja organisasi pertanian dalam bidang pengairan irigasi baru dapat dicapai sebesar $62,10 \%$ dalam kondisi baik. Hal ini berdampak pada masa tanam yang diharapkan bisa tiga kali per tahun namun pada praktiknya para petani penggarap sawah rata-rata hanya dapat bercocok tanam padi dua kali per tahun.

Kedua: managerial systems, yaitu sistem managerial yang menitikberatkan pada proses adaptasi dan integrasi dengan lingkungan internal dan eksternal, dalam rangka menjalin hubungan kerjasama dalam suatu tujuan belum dapat sepenuh- 
nya berhasil dilaksanakan oleh Pemerintah Daerah yang telah mendelegasikan proses implementasi kebijakan kepada Dinas Pertanian Tanaman Pangan dan OPD lain. Dalam hal ini, organisasi-organisasi terkait dalam sektor pertanian belum dapat berkolaborasi sepenuhnya sehingga proses beradaptasi, integrasi dan kerja sama antar kelembagaan untuk pencapaian tujuan organisasi tidak dapat sepenuhnya dilakukan secara maksimal. Hal ini terlihat dari indikator ways of creating knowledge dari dimensi kapabilitas organisasi managerial systems, yang mana dengan indikator tersebut kapabilitas organisasi Pemerintah Daerah dapat menjalankan upaya-upaya mencipta-kan ilmu pengetahuan, programprogram pembelajaran organisasi sebagai arena membuat jaringan-jaringan kerja dengan sejumlah partner di lingkungan pekerjaan. Indikator ways of creating knowledge ini belum dapat diimplementasikan sepenuhnya dalam kapabilitas organisasi-organisasi perangkat daerah yang terkait dalam upaya peningkatan produktivitas dan produksi komoditas padi di Kabupaten Subang tahun 2016 sampai 2018. Secara teknis, hal ini terlihat dari realisasi produksi komoditas padi tahun 2018 sebesar $1.366 .575,57$ ton dan produktivitasnya mencapai 71,60 kw/ha.

\section{DAFTAR PUSTAKA}

\section{Buku:}

Bogdan, Robert dan Taylor, Steven J. 1992. Pengantar Metode Penelitian Kualitatif. Surabaya: Usaha Nasional.

Koontz, Harold; O'Donnell, Cyril dan Weihrich, Heinz. 1991. Manajemen. Edisi Kedelapan, Jakarta: Penerbit Erlangga.

Strauss, Anselm dan Corbin, Juliet. 2003. Dasar-dasar Penelitian Kualitatif. Yogyakarta: Pustka Pelajar.

Whitley, Richard. 2007. Business Systems and Organizational Capabilities. New York: Oxford University Press.

\section{Jurnal:}

Arshad, et al. 2011. Food Security: SelfSufficiency of Rice in Malaysia.

Azwardi, et al. 2006. The Effect of Subsidy Policy on Food Security of Rice in Indonesia.

Collis, David J. 1994. "How Valuable Are Organizational Capabilties?". Strategic Management Journal 15, Suppl (1): 143-152.

Leonard \& Barton. 1992. "Core Capabilities and Core Rigidities: A Paradox in Managing New Product Development". Strategic Management Journal, Vol. 13, Special Issue: Strategy Process: Managing Corporate. SelfRenewal. (Summer, 1992), pp. 111125.

Talbot, Colin and Johnson, Carole. 2007. "Seasonal Cicles in Public Management: Disagreggation and $\mathrm{Re}$ aggregation". Public Money \& Management, 27: 53-60.

Winter, Sidney G. 2003. "Understanding Dynamic Capabilities". Strategic Management Journal, 24: 991-995.

\section{Dokumen:}

Dinas Pertanian Tanaman Pangan Kabupaten Subang Tahun 2018 tentang Capaian Kinerja Dalam Produksi dan Produktivitas Komoditas Padi Tahun 2016-2018.

\section{Peraturan Perundang-Undangan:}

Keputusan Menteri Pertanian Republik Indonesia Nomor 1243/Kpts/OT.160/ 12/2014 tentang Kelompok Kerja Upaya Khusus Peningkatan Produksi Padi, Jagung, dan Kedelai.

Peraturan Daerah Nomor 14 Tahun 2014 tentang Rencana Pembangunan Jangka Menengah Daerah Kabupaten Subang Tahun 2014-2018.

\section{Laman:}

Tempo. co, Subang, 27 Desember 2014. 